\title{
PROJEKT OPTIMALNA UČINKOVITOST DELAVCEV
}

\section{Zagotavljanje kakovosti pri izobraževanju proizvodnih delavcev}

$P_{0}$

odjetje Revoz si je zadalo nalogo, da bo svojim proizvodnim delavcem omogočilo izboljšanje znanja in napredovanje na delovnih mestih, zato smo začeli izvajati projekt postopnega izobraževanja Optimalna učinkovitost delavcev. Spoznali smo namreč, da bomo le $\mathrm{z}$ znanjem in stalnim usposabljanjem vseh zaposlenih lahko dosegli cilje podjetja.

Pri strokovnem usposabljanju delavcev gre za uvajanje nepretrganega interaktivnega postopka, ki omogoča sistematično povezavo med izobraževanjem, delom in delovnim okoljem.

V sklopu izobraževanja delavcev gre tudi za možnost razvoja organizacije dela na podlagi razvoja delavcev, pri čemer je premajhna prožnost delno posledica težav, do katerih prihaja pri prilagajanju in razvoju delavcev.

Projekt usposabljanja proizvodnih delavcev smo imenovali Optimalna učinkovitost delavcev. Program izobraževanja ponuja proizvodnim delavcem različnih ravni predvsem te možnosti:

- razširiti njihovo strokovno znanje,

- prilagajanje spremembam v vodenju, organizaciji in tehnologiji,

- razvijanje novega pristopa $\mathrm{k}$ delu.

Izboljševanje znanja delavcev zagotavlja večjo samostojnost, odgovornost delavcev, hitrejši razvoj organizacijske strukture in večje zaupanje med ljudmi na podlagi izboljšanja komunikacije v osnovnih delovnih enotah.

\section{PROGRAMSKA NAČELA}

Program temelji na doslednem spoštovanju naslednjih načel:

- prostovoljnost: vsak delavec ima ne glede na svoje znanje, sposobnosti ali delovno dobo možnost, da se vključi v projekt Optimalna učinkovitost delavcev; raven splošnega znanja ni ovira pri vključevanju v postopek strokovnega usposabljanja;

- prilagojen pedagoški pristop - pedagoški pristop temelji na običajnih aktivnostih delavcev; ritem izobraževanja je prilagojen sposobnostim sprejemanja novih znanj;

- vključevanje vodstvene strukture - za uspešno realizacijo programa je bistveno vključevanje vodstvenih delavcev; vodstveni delavci $\mathrm{v}$ proizvodnji morajo biti vključeni v proces že pri za-
Izobraževanje delavcev pomeni tudi napredovanje na delovnih mestih. snovi, pa tudi pri postopku uvajanja uporabe novih znanj v proizvodnji;

- povezava $\mathbf{z}$ delovnim okoljem - vsebina izobraževanja je povezana s konkretnimi razmerami v delovnem okolju;

- izobraževanje med delovnim časom - večji del izobraževanja poteka med rednim delovnim časom, vendar se morajo delavci vključevati v nekatere oblike izobraževanja tudi zunaj delovnega časa. REVOZ

Novo mesto 
Namen programa je zmanjšati razliko med sedanjo ravnjo znanja delavcev in ravnjo, potrebno za izvajanje nalog na osnovi nove organizacije dela. Nekaterim delavcem bo ta program omogočil lažji dostop do dodatnih oblik usposabljanja, potrebnih zaradi na novo zahtevane strokovnosti. Program za strokovno usposabljanje mora vsem delavcem omogočiti vključitev v izobraževalni proces, ki je prilagojen njihovi ravni in njihovim potrebam.

\section{SESTAVA PROGRAMA}

Program Optimalna učinkovitost delavcev je sestavljen iz usmeritvenega izobraževalnega programa, dveh izobraževalnih programov, ki ustrezajo dvema stopnjama, in enega izobraževalnega programa za prehod med dvema stopnjama.

Izobraževalni program Izobraževanja-Pregled znanja-Usmeritev je prva faza, to je vstop v proces. Dostopen je vsem delavcem, ne glede na njihovo raven; cilj tega programa je pripraviti delavca, da sam naredi pregled svojega znanja in opredeli svojo usmeritev v enega od dveh stopenjskih izobraževalnih programov.

Cilj izobraževalnega programa na 1. stopnji je opredeliti in razviti strokovno znanje delavcev. Zadeva delavce, katerih znanje izhaja zgolj iz njihovih delovnih izkušenj, zato ne izpolnjujejo pogojev za pristop $\mathrm{k}$ izobraževanju na 2. stopnji.

Cilj izobraževalnega programa na 2. stopnji je

Odločitev, na kateri stopnji bo delavec nadaljeval izobraževanje, se sprejme na tako imenovanem tripartitnem razgovoru, $\mathrm{v}$ katerem sodelujejo delavec oziroma udeleženec, vodja oziroma njegov nadrejeni in izobraževalec, ki je vodil izobraževanje. Udeleženec predstavi svoje mnenje o veščinah, znanju in vedenjskih lastnostih, ki ga je pripravil med izobraževanjem na podlagi različnih vaj. izboljšati strokovno usposobljenost, in sicer z razvojem znanja z različnih vidikov dela, ki ga opravljajo. Za to obliko izobraževanja morajo delavci izpolnjevati ustrezne pogoje.

V sklopu 2. stopnje so štirje splošni moduli, in sicer:

- kakovost,

- obdelava informacij in komuniciranje,

- reševanje problemov,

- vzdrževanje 1. stopnje in

- poklicni modul.

Povezani so z izobraževalnim programom na 3. stopnji - priprava na novo delo, izobraževanje. Po končanem programu morajo delavci narediti test s strokovnega področja. Sodelovanje delavcev pri tej obliki izobraževanja je odvisno od potreb podjetja in tudi od soglasja nadrejenih.

Izobraževalni program Prehod 1. stopnja/2. stopnja omogoča lažji prehod delavcev s 1 . na 2. stopnjo. Cilj tega izobraževalnega programa je omogočiti delavcem pridobiti manjkajoče znanje, da bi bili uspešni na 2. stopnji.

\section{Zagotavljanje kakovosti pri programu Optimalna učinkovitost delavcev}

V podjetju Revoz kakovost vključujemo v vsa področja delovanja, zato je izredno pomembna tudi pri izobraževalnemu procesu.

$\mathrm{Z}$ vidika globalnega procesa izobraževanja $\mathrm{v}$ podjetju se upošteva potreba po izobraževanju, ki jo je treba analizirati. Analizi sledita določitev splošnih pogojev izobraževanja in iskanje ponudb za izvajanje. Naslednja faza so ocena ponudb, izbira izvajalcev in sklenitev pogodbe za izvajanje. Sledijo izvedba izobraževanja in ocena pridobljenega znanja, prenos znanja na teren oziroma uporaba znanja in po določenem obdobju ocenjevanje učinkovitosti izobraževanja.

Po pripravljenem programu se na podlagi 


\section{PROGRAM: OPTIMALNA UČINKOVITOST DELAVCEV}

STROKOVNOST 1

F. B. 0 .

PREGLED

IZOBRAŽEVANJE

USMERITEV
STROKOVNOST 2

STROKOVNOST 3

\section{MODUL \\ - OBDELAVA INFORMACIJ IN KOMUNICIRANJE}

\section{MODUL}

- KAKOVOST

\section{MODUL}

- REŠEVANJE PROBLEMOV

\section{MODUL}

- VZDRŽEVANJE 1. RAVEN

\section{MODUL}

- POKLICNI MODUL analize, vezane na specifičnost programa, izberejo možne ponudbe za izvajalce izobraževalnega programa.

Za projekt Optimalna učinkovitost delavcev imamo zunanje in interne izvajalce, ki imajo visoko izobrazbo in so strokovnjaki na njihovem področju dela.

Pri zunanjih izvajalcih se zahtevajo predvsem visoka stopnja strokovnosti, kakovost dela in pogoj, da se prilagodijo specifičnostim in zahtevam, ki jih postavi podjetje.

Druga možnost za izvajanje programa so interni izobraževalci. To so strokovnjaki iz podjetja, ki so specialisti za določena področja in tudi usposobljeni za prenos znanja $\mathrm{z}$ vidika pedagogike in andragogike.

Drugi izobraževalci se usposobijo za izvajanje projekta Optimalna učinkovitost delavcev tako, da se udeležijo programa Optimalna učinkovitost delavcev, ki jo v začetni fazi vodi vodja projekta.

\section{Spremljanje in ocenjevanje izobraževanja}

Kakovost oziroma učinkovitost izobraževanja spremljamo z ocenjevanjem izobraževanja po končanem, izobraževanju, metodo MAQF in analizo z vodji ODE.

\section{Ocenjevanje po končanem izobraževanju}

Udeleženci ocenijo izobraževanje takoj po končanem izobraževanju z ocenjevalnim listom za udeležence.

Ocenjujejo:

- uporabnost pridobljenega znanja,

- koliko je izobraževanje izpolnilo njihova pričakovanja,

- potek, strukturo in vsebino izobraževanja,

- predavatelja,

- sprejem in organizacijo,

- splošen vtis. 
Poleg tega udeleženci navedejo prednosti oziroma slabosti izobraževanja in odgovorijo na vprašanje, kako bodo pridobljeno znanje uporabili pri svojem delu. Pri naslednjih skupinah skušamo odpraviti slabosti izobraževanja tudi na podlagi predlogov, ki jih dajo udeleženci.

Možne ocene so zelo dobro, dobro, slabo ali zelo slabo. Izobraževalni center ima v svojih ciljih določeno tudi raven za doseganje ocene izobraževanja, to je 4,5. Izračunavanje in spremljanje ocene izobraževanja poteka vsak teden oziroma takoj po končanem izobraževanju.

Podatki kažejo, da je ocena projekta Optimalna učinkovitost delavcev vedno nad postavljenim ciljem in da gre za program izobraževanja, pri katerem dosegamo najvišje ocene. Tudi pripombe oziroma predlogi udeležencev so izredno pozitivni in kažejo željo po nadaljnjem vključevanju v program izobraževanja.

Če pa ugotovimo, da je ocena pod pričakovanim ciljem, z izvajalcem izobraževanja na skupnem sestanku skušamo ugotoviti, kje so težave in pomanjkljivosti, ki jih je treba odpraviti.

\section{Spremljanje učinkovitosti izobraževanja - MAQF}

Zaradi pomanjkanja meril za merjenje kakovosti in izboljšanje strokovnosti funkcije izo-

Renault je izdelal
svojo metodo za
zagotavljanje ka-
kovosti izobraževa-
nja-MAQF.
braževanja $\mathrm{v}$ podjetjih so $\mathrm{v}$ matičnem podjetju Renault izdelali metodo za zagotavljanje kakovosti izobraževanja MAQF.

Metoda temelji na sistematičnem spremljanju in preverjanju skozi celoten proces izobraževanja in ima več faz:
- sinteza analize zahteve (določimo, kaj bi radi dosegli, cilje spremembe, pogoje izvedbe);

- določitev splošnih pogojev izobraževanja (trenutno stanje, namen, pričakovani rezultati, cilji izobraževanja, ciljna skupina, po- goji za izvedbo, predvidena sredstva za izvedbo, literatura);

- pedagoški cilji, ki ustrezajo splošnim pogojem;

- pedagoški koncept (gradivo izobraževalca, vodnik za animacijo, pedagoška sredstva, metode ocenjevanja, metode komuniciranja);

- organizacija in logistika (kraj izvedbe, datum izvedbe, urnik, spisek udeležencev, spisekizobraževalcev);

- izvedba (bilanca izobraževanja, izvajalci, udeleženci);

- administrativno upravljanje (realizacija udeleženci, ure, kraj izvajanja, proračun);

- spremljanje in prenos na teren (upoštevanje pripomb udeležencev v zvezi z nadaljnjimi seminarji);

- sodelovanje in vključevanje hierarhije (vodja pojasni, kaj pričakuje od udeleženca po izobraževanju, ciljna raven ali cilj).

Po končanem izobraževanju se po obdobju 3 ali 6 mesecev z vprašalniki preverja učinkovitost izobraževanja. Nadrejeni in izvajalec dobita vprašalnik, s katerim se ugotavlja učinkovitost izobraževanja, ki se ga je delavec udeležil. Če so se spoštovale posamezne faze pri pripravi in izvedbi izobraževanja, je tudi učinkovitost izobraževanja dobra, kar je razvidno iz obdelave podatkov na osnovi metode MAQF.

Metoda MAQF je računalniški program, ki omogoča:

- obdelavo in analizo vprašalnikov,

- diagnostiko postopka pri organizaciji in izvedbi izobraževanja,

- pripravo poročila o oceni posameznih oblik izobraževanja (zadovoljstvo kupcev in spoštovanje postopka).

Ocenjevanje $\mathrm{z}$ metodo MAQF je izhodišče za pripravo plana aktivnosti izobraževalne institucije in omogoča napredek na ustreznem področju. 
Obdelava podatkov z metodo MAQF kaže na veliko učinkovitost oziroma visoko oceno postopka (95 odstotkov) z vidika primernosti, organizacije, spoštovanja rokov in stroškov glede na program Optimalna učinkovitost delavcev. Malce nižja (80 odstotkov) je ocena v zvezi s komunikacijo. Iz tega lahko sklepamo, da komunikacija na ravni delavec-nadrejeni ne poteka zadovoljivo. Nadrejeni mora namreč delavca usmeriti oziroma napotiti na izobraževanje tako, da ima prej s podrejenim pogovor o cilju in pomenu izobraževanja.

Analiza kaže tudi na zelo dobro sodelovanje izobraževalnega centra in vodstvene strukture pri pripravi, organiziranju, obveščanju (95 odstotkov).

\section{Analiza $\mathrm{z}$ vodji}

Tretja možnost za spremljanje učinkovitosti oziroma kakovosti izobraževalnega programa Optimalna učinkovitost delavcev je analiza $\mathrm{z}$ vodji ODE, katerih podrejeni so bili vključeni v program. $Z$ analizo ugotovimo:

- pozitivna opažanja pri delavcih,

- negativna opažanja pri delavcih,

- razloge za spremembe pri delavcih,

- ali program prinaša pričakovane spremembe,

- ali imajo dovolj informacij o vsebini in poteku programa,

- težave zaradi udeležbe delavcev,

- pričakovanja glede nadaljnjega izobraževanja.

Iz analize povzemamo, da je bistveno pozitivno opažanje večja samostojnost delavcev, negativnih opažanj ni. Razlogi za spremembe pri delavcih se $\mathrm{v}$ zainteresiranosti in značaju posameznika. Program izobraževanja prinaša pričakovane spremembe. Največja ovira, ki se pojavlja, so predvsem organizacijske težave, in sicer pomanjkanje delavcev - velik absentizem.

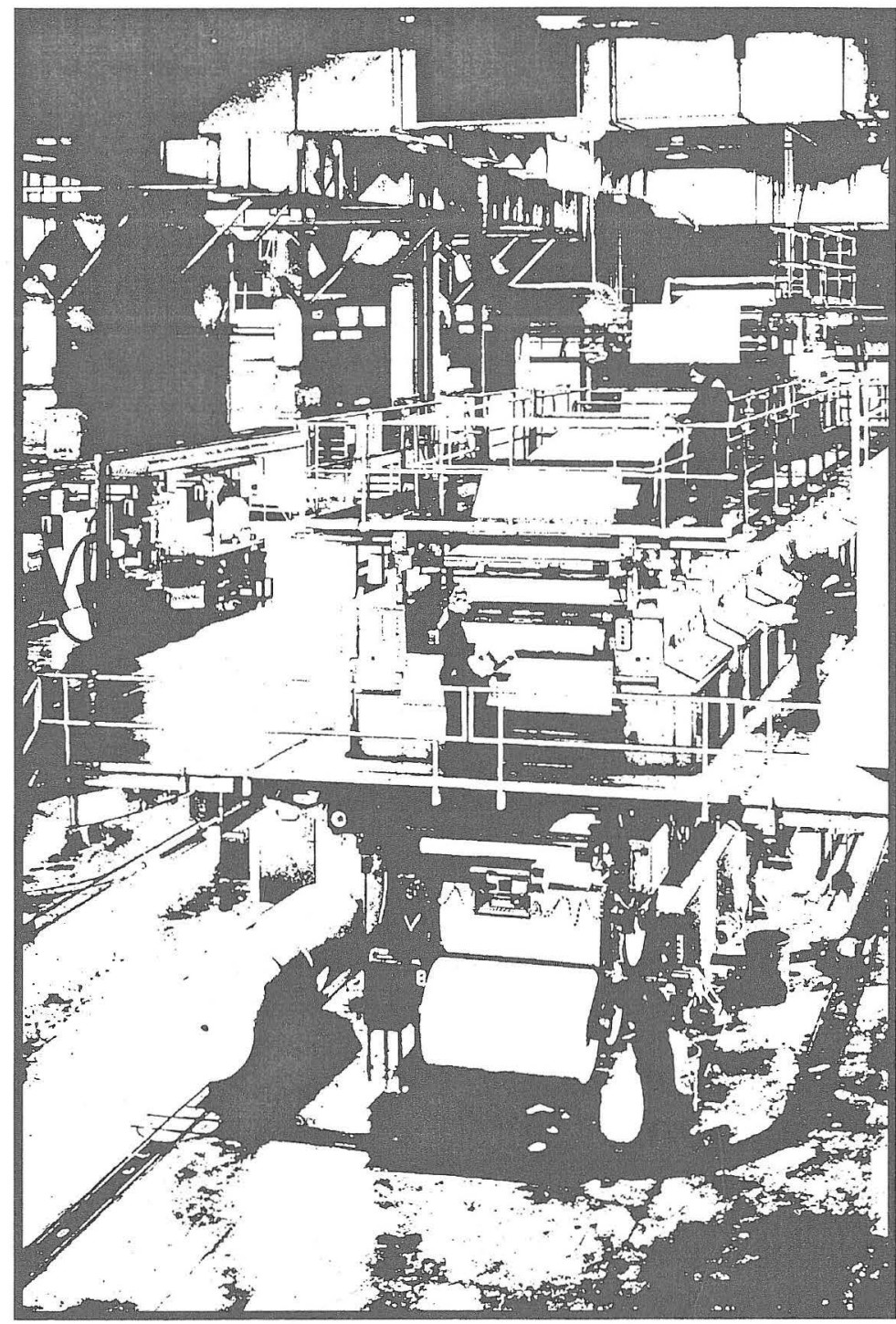

V izobraževalnem centru ugotavljamo, da je potrebno stalno spremljanje kakovosti oziroma učinkovitosti izobraževalnih programov. Če se ugotovijo težave ali odmiki od programa, jih je treba odpraviti. 